\title{
Role of the Nutritional Condition of Breeding Anchovies in the Subsequent Recruitment to their Population in the Bay of Biscay (NE Atlantic)
}

\author{
Jean-Pierre Bergeron* and Jacques Masse
}

IFREMER, Centre Atlantique, Département Écologie et Modèles pour l'Halieutique (EMH), rue de I'lle d'Yeu, BP 21105, F-44311 Nantes Cedex 03, France

*: Corresponding author : Jean-Pierre Bergeron, email address : jean.pierre.bergeron@ifremer.fr

\begin{abstract}
:
The recruitment of marine fish populations is a central concern of fisheries scientists. Multiple research pathways have been explored, with emphasis of the causes of mortality affecting principally the early developmental stages of fish life. The small data set presented focuses on a feature often inadequately considered, i.e. the nutritional condition of the breeding parent fishes estimated from the levels of the RNA/DNA ratio determined in fish white muscle. This is applied to the European anchovy population inhabiting the French continental shelf of the North-East Atlantic Ocean. In four of the five years analysed, the annual recruitment shows a tight relationship with the mean values for the RNA/DNA ratio determined in the parent fish during the previous breeding season. One year is clearly distinguished from this model, owing to a strong drop of the recruitment, of which an explanation is tentatively advanced. This drop coincides with the beginning of a strong collapse of the population. A very low level of the anchovy biomass will last ten years. The role of the nutrition of breeding fish in the recruitment success is discussed in connection with the literature that emphasized the importance of conditions providing fish with sufficient fuel during the crucial period of its gametogenesis, particularly in clupeoids and anchovies.
\end{abstract}

Keywords: anchovy ; Bay of Biscay ; breeding season ; recruitment ; RNA/DNA ratio 


\section{Introduction}

It is widely accepted by fisheries scientists that the recruitment of marine fish populations is a central concern in improving fisheries management. The mechanisms thought to be involved in regulating this recruitment are numerous and their possible interactions complex, notably because they may evolve in space and time during the ontogenesis of most species. Therefore, multiple research pathways have been explored, with emphasis on the causes of mortality linked to either biotic factors, such as starvation (e.g., Ferron and Leggett, 1994) and predation (e.g., Leggett and DeBlois, 1994), or abiotic factors (Bergeron, 2000; MacKenzie, 2000) during the early developmental stages of life (Govoni, 2005).

Fewer studies have suggested that the condition of the parental population plays a major role, as cited in recent studies ( Rosa et al., 2010; Sutharshiny and Sivashanthini, 2011). Here, we introduce new data in a similar spirit, using another biochemical tool-the RNA/DNA ratio (the quantitative ratio of ribonucleic acid to deoxyribonucleic acid), which is widely used to study a number of marine organisms, in particular fish larvae (for a review, see Bergeron, 1997), although less commonly directed toward larger animals (although a study based on the same index was recently published by Pulgar et al., 2011). The RNA/DNA ratio has also proved to be a reliable index of nutritional condition when determined in the white muscle of adult fish (Lied et al., 1983). This ratio is used with increasing frequency (Chicharo and Chicharo, 2008) and our research team began its routine implementation in 1993, within the framework of ecological surveys of small pelagic fish populations, especially of the anchovy (Engraulis encrasicolus L.). These studies were carried out on the French continental shelf in the Bay of Biscay (NE Atlantic) to identify variations in the spatial distributions, abundance, and main environmental factors that might explain fluctuations in recruitment.

\section{Materials and methods}

Six spring surveys were conducted between 1993 and 2001 on board the French RV Thalassa during the peak of the anchovy breeding season (late April-early June). The determinations of the RNA/DNA ratio ceased after 2001, so the available series is relatively short. The survey of the small pelagic fish community was made with acoustic methods, which allowed us to detect the presence of shoals worthy of sampling by pelagic trawling. The individuals subjected to nucleic acid analysis were taken from the catch (14-23 trawls per cruise, 15-18 individuals per catch). All details of the sampling process and analytical procedures have been recently published (Bergeron and Massé, 2011).

\section{Results and discussion}

Unlike other anchovy species that may spawn twice a year such as the Japanese Engraulis japonicus (Ahmed et al., 2001; Ahmed and Osawa, 2002), Engraulis encrasicolus in the Bay of Biscay spawns only once a year in spring-early summer. Because the anchovy is a shortlived species, reaching sexual maturity one year after hatching, one-year-old individuals enter the fishery at this age and these recruits constitute at least $75 \%$ of the annual catch (Uriarte et al., 1996). Therefore, the recruitment of anchovy in the Bay of Biscay is estimated from the difference, expressed as a percentage, between the number of individuals inhabiting the fishery area in a given year and the number of recruits found the following year (Table 1). In four of the five years analysed, the annual recruitment showed a tight relationship with the mean values for the RNA/DNA ratio determined in the white muscle of the parent fish during the previous breeding season (Fig. 1). 
This relationship was only apparent in four years, although the index for the parental nutritional condition was determined on six cruises, so the data for two years (1993 and 2001) were inconsistent with the model. These discrepancies may be explained by several events. First, as recently shown (Bergeron and Massé, 2011), an unusual wind event occurred in 1993 during the cruise and disturbed the environmental conditions. This unexpected event led the scientific team on board the RV Thalassa to modify the initially defined strategy so that they could study the consequences of wind stress at a fine scale. This explains why the data set for the nutritional condition of the breeding anchovies collected in 1993 were considered to be unusable, and were not taken into account in the analysis described here. Second, in the year 2001, the unexplained very low recruitment rate was an early sign of the collapse of the population (Petitgas et al., 2010), which lasted for several years, at least until 2010 (ICES, 2010). This serious situation was amplified one year later, in 2002, probably because of the simultaneous occurrence of other factors. Among these, the weak nutrient enrichment from the discharge of a large river was especially striking (Bergeron et al., in prep.).

The anchovy population in the Bay of Biscay is a very important resource shared by the Spanish and French fishing fleets. As mentioned above, the success of the annual recruitment plays a central role in the catches of these fleets. For this reason, fisheries scientists have focused on understanding the environmental factors potentially involved in the regulation of the annual stock abundance, i.e., the conditions that favour good recruitment in this short-lived species and those that preclude it. Empirical models founded on theoretical knowledge of the factors known to enhance biological productivity in marine ecosystems led to initial success and promising early results at the turn of the century (Borja et al., 1996; Allain et al., 2001). These studies principally took into account abiotic factors, such as wind strength and direction (which induce upwelling processes if moderate or have deleterious consequences if too strong) or river inflows (which introduce low-salinity nutrientenriched water). Biotic factors have also drawn the attention of a few researchers, notably the quantitative spatial distribution of zooplankton (Irigoien et al., 2009) or metabolic descriptors of the biotic environment (Bergeron et al., 2010). No really decisive advances were made with these attempts.

We have described a new method of recruitment analysis based on an often-overlooked concept, the nutritional status of the breeding parent fish. This approach resembles or at least shares its inspiration with a recently published study of small pelagic fish in the upwelling off the western Portuguese coast (Rosa et al., 2010), although our data set is weaker because it is very much smaller than the set of Rosa et al. (2010). Our ultimate goal is clearly not reached in this study. Nevertheless, a clear positive trend is apparent, which could point to the importance of this factor in the recruitment of small pelagic fish stocks. A recent study (Bergeron and Massé, 2011) provided an opportunity to emphasize the role of the nutritional condition of multiple spawner fishes in the success of the breeding season. Because nutrition plays an essential role in sustaining gametogenesis in fish, the phenomenon proposed in this study may have consequences for the overall fecundity of the anchovy population.

In a review of the biology of clupeoid fishes, Blaxter and Hunter (1982) showed that a large majority of these small pelagic species reproduce using multiple (serial or asynchronous) spawning strategies. Motos (1996) confirmed that the Bay of Biscay anchovy is a multiple spawner, with asynchronous oocyte development. De novo vitellogenesis is a continuous process during the reproductive season and all oocyte stages are present at the same time in the ovary. Motos (1996) estimated that during an annual spawning season, the Bay of Biscay anchovy can spawn about 19-20 times. This number is very close, if not quite identical (20), to that established by Hunter and Leong (1981) for the northern anchovy Engraulis mordax. These authors reported that because the caloric equivalent of only two spawnings exists in the ovary at any one time, northern anchovies must use the energy 
stored in other tissues and their food intake to support their reproduction. They also calculated that a daily ration of copepods equivalent to $4 \%-5 \%$ of the female wet weight is required to support the annual cost of growth and reproduction. It is quite possible that the European anchovy inhabiting the Bay of Biscay has even larger metabolic requirements, given its highly dynamic growth and sexual maturation characteristics (Motos, 1996).

In short, the potential success of recruitment to the anchovy population in the Bay of Biscay seems to be, at least partly, estimated from the nutritional condition of the spawners during the previous breeding season. The case observed in 2001 does not conform to this view and illustrates the limits of this approach. The succession of low recruitment rates experienced by the anchovy population since 2001 has led researchers to other factors that act at larger scales than those previously studied (Borja et al., 2008). The 2001 spawning season was characterized by extremely high outflow rates from the Gironde estuary, and despite its rather good effect on the pelagic ecosystem enrichment in nutrients and the subsequent improvement of the nutritional condition of the anchovies (Bergeron et al., 2010), this had negative consequences for recruitment, possibly linked to the excessive scattering of eggs and larvae from the spawning ground (as noticeable in Bergeron et al., 2010, nuclei of less saline water were found in front of the mouths of rivers and moved away from the coast under the effect of northwesterly winds, according to P. Lazure, IFREMER-Centre Bretagne, personal communication). This is also consistent with the findings of quantile regression models of fish recruitment-environment relationships (Planque and Buffaz, 2008).

The data set presented here is too small to be considered really significant. However, it can be seen to offer a narrow window onto a feature inadequately addressed in the literature, which plays a prominent role, among other factors, in the recruitment of small pelagic fish.

\section{Acknowledgements}

We are greatly indebted to the whole team of colleagues who contributed to the execution of the research cruises, in particular Patrick Grellier for his management of the sorting of trawled fishes and Nathalie Rétière for carrying out biochemical analyses. Thanks are due to officers and crew of the RV Thalassa. This study was carried out within the framework of the Programme National sur le Déterminisme du Recrutement" (PNDR), a French contribution to the GLOBEC (SPACC) International Program. From 2000 onwards, the study was conducted with the financial support of the French Programme National d'Ecologie Côtière"/atelier Gascogne (PNEC- Gascogne), and the fisheries research part of the survey was partially financed by the European Commission, DG XIV, under the research project PELASSES n`99/010.

\section{References}

Ahmed, Z.F. and T. Ozawa, 2002. Annual egg production of seasonal populations of Japanese anchovy (Engraulis japonicus) in Kagoshima Bay, Southern Japan. Pak. J. Biol. Sci., 5: 728-732.

Ahmed, Z.F., Ozawa, T., Hayama, T. and Y. Masuda, 2001. Identification of seasonal populations of Japanes anchovy, Engraulis japonicus in Kagoshima Bay, Japan by examination of otolith-rings. Pak. J. Biol. Sci., 4: 1440-1445.

Allain, G., P. Petitgas and P. Lazure, 2001. The influence of mesoscale ocean processes on anchovy (Engraulis encrasicolus) recruitment in the Bay of Biscay estimated with a three-dimensional hydrodynamic model. Fish. Oceanogr., 10: 151-163. 
Bergeron, J.-P., 1997. Nucleic acids in ichthyoplankton ecology: a review, with emphasis on recent advances for new perspectives. J. Fish Biol., 51 (Suppl. A): 284-302.

Bergeron, J.-P., 2000. Effect of strong winds on the nutritional condition of anchovy (Engraulis encrasicolus L.) larvae in the Bay of Biscay, Northeast Atlantic, as inferred from an early field application of the DNA/C index. ICES J. Mar. Sci., 57: 249-255.

Bergeron, J.-P., and J. Massé, 2011. Change in the shoaling behaviour and nutritional condition of anchovies (Engraulis encrasicolus L.) during a wind-induced water column disturbance: a natural event test of a general hypothesis. Mar. Freshw. Behav. Physiol.

Bergeron, J.-P., D. Delmas, and N. Koueta, 2010. Do river discharge rates drive the overall functioning of the pelagic ecosystem over the continental shelf of the Bay of Biscay (NE Atlantic)? A comparison of two contrasting years with special reference to anchovy (Engraulis encrasicolus L.) nutritional state. J. Oceanogr., 66: 621-631.

Blaxter, J.H.S. and J.R. Hunter, 1982. The biology of clupeoid fishes. Adv. Mar. Biol., 20: 1223.

Borja, Á., A. Uriarte, A. Valencia, L. Motos L. and A. Uriarte, 1996. Relatioship between anchovy (Engraulis encrasicolus L.) recruitment and the environment in the Bay of Biscay. Sci. Mar., 60 (Suppl. 2): 179-192.

Borja, Á., A. Fontán, J. Sáenz and Valencia V., 2008. Climate, oceanography, and recruitment: the case of the Bay of Biscay anchovy (Engraulis encrasicolus). Fish. Oceanogr., 17: 477-493.

Chicharo, M.A. and L. Chicharo, 2008. RNA:DNA ratio and other nucleic acid derived indices in marine ecology. Int. J. Mol. Sci., 9: 1453-1471.

Ferron, A. and W.C. Leggett, 1994. An appraisal of condition measures for marine fish larvae. Adv. Mar. Biol., 30: 217-303.

Govoni, J.J., 2005. Fisheries oceanography and the ecology of early life histories of fishes: a perspective over fifty years. Sci. Mar., 69 (Suppl. 1): 125-137.

Hunter, J.R. and R. Leong, 1981. The spawning energetics of female northern anchovy, Engraulis mordax. Fish. Bull., 79: 215-230.

ICES, 2010. Report of the working group on anchovy and sardine (WGANSA), 24-28 June 2010, Vigo, Spain. 285 pp.

Irigoien, X., J.A. Fernandes, P. Grosjean, K. Denis, A. Albaina and M. Santos, 2009. Spring zooplankton distribution in the Bay of Biscay from 1998 to 2006 in relation with anchovy recruitment. J. Plankton Res., 31: 1-17.

Leggett, W.C. and E. DeBlois, 1994. Recruitment in marine fishes: is it regulated by starvation and predation in the egg and larval stages? Netherlands J. Sea Res., 32: 119-134.

Lied, E., G. Rosenlund, B. Lund and A. von der Decken, 1983. Effect of starvation and refeeding on in vitro protein synthesis in white trunk muscle of Atlantic cod (Gadus morhua). Comp. Biochem. Physiol., 76B: 777-781.

MacKenzie, B.R., 2000. Turbulence, larval fish ecology and fisheries recruitment: a review of field studies. Oceanol. Acta, 23: 357-375.

Motos, L., 1996. Reproduction biology and fecundity of the Bay of Biscay anchovy population (Engraulis encrasicolus L.). Sci. Mar., 60 (Suppl. 2): 195-207.

Petitgas P., D.H. Secor, I. McQuinn, G. Huse and N. Lo, 2010. Stock collapses and their recovery: mechanisms that establish and maintain life-cycle closure in space and time. ICES J. Mar. Sci., 67: 1841-1848.

Planque, B. and L. Buffaz, 2008. Quantile regression models for fish recruitmentenvironment relationships: four case studies. Mar. Ecol. Prog. Ser., 357: 213-223.

Pulgar, J., M. Alvarez, J. Morales, M. Garcia-Huidobro, M. Aldana, F.P. Ojeda and V.M. Pulgar, 2011. Impact of oceanic upwelling on morphometric and molecular indices of an intertidal fish Scartichthys viridis (Blenniidae). Mar. Freshw. Behav. Physiol., 44: 33-42.

Rosa, R., L. Gonzalez, B.R. Broitman, S. Garrido, A.M.P. Santos and M.L. Nunes, 2010. Bioenergetics of small pelagic fishes in upwelling systems: relationship between fish condition, coastal ecosystem dynamics and fisheries. Mar. Ecol. Prog. Ser., 410: 205218. 
Sutharshiny, S. and K. Sivashanthini, 2011. Lipid reserves of Scomberoides lysan (Pisces: Carangidae) from the Sri Lankan waters. Int. J. Biol. Chem., 5: 170-183.

Uriarte, A., P. Prouzet and B. Villamor, 1996. Bay of Biscay and Ibero Atlantic anchovy populations and their fisheries. Sci. Mar., 60(Suppl. 2): 237-255.

\section{Tables}

Table 1. Details of the data used for establishing the relationship presented in Fig. 1.

\begin{tabular}{|c|c|c|c|c|c|c|}
\hline \multirow{2}{*}{$\begin{array}{l}\text { Dates of } \\
\text { cruises }\end{array}$} & \multirow[t]{2}{*}{ Year Y } & \multicolumn{2}{|c|}{ RNA/DNA } & \multirow{2}{*}{$\begin{array}{c}\text { number ind. } \\
\text { analysed }\end{array}$} & \multirow[t]{2}{*}{$R^{*}(.1000 t)$} & \multirow{2}{*}{$\begin{array}{r}\% \text { variation } \\
(\mathrm{Y}+1-\mathrm{Y})\end{array}$} \\
\hline & & mean value & standard dev. & & & \\
\hline \multirow[t]{2}{*}{$15 / 05-08 / 06$} & 1994 & 2.83 & 1.62 & 120 & 48.4 & 0.125 \\
\hline & 1995 & & & & 53.8 & \\
\hline 06/05-03/06 & 1997 & 3.51 & 1.43 & 210 & 51.6 & 0.577 \\
\hline \multirow[t]{2}{*}{$23 / 05-21 / 06$} & 1998 & 2.41 & 0.59 & 315 & 82 & -0.024 \\
\hline & 1999 & & & & 79.7 & \\
\hline $16 / 04-15 / 05$ & 2000 & 1.68 & 0.62 & 285 & 127.7 & -0.344 \\
\hline $26 / 04-06 / 06$ & 2001 & 2.77 & 0.74 & 345 & 83.8 & -0.845 \\
\hline 06/05-08/06 & 2002 & & & & 13 & \\
\hline
\end{tabular}

* drawn from ICES, 2010 


\section{Figures}

Figure 1. Variations in the annual recruitment $(R)$ of the anchovy population in the Bay of Biscay as a function of the mean RNA/DNA ratios determined in the white muscle of individual fish during the breeding season of the preceding year.

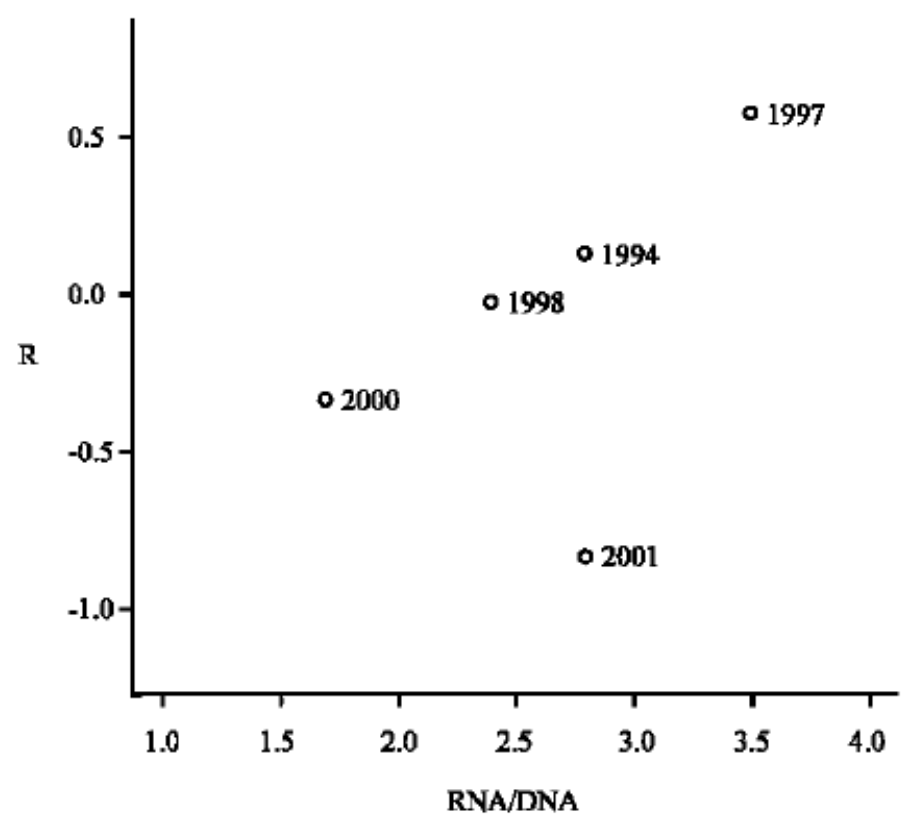

